Plant Tissue Cult. \& Biotech. 27(1): 41-50, 2017 (June)

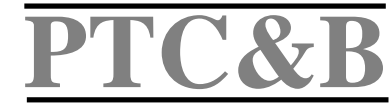

\title{
Embryogenic Callus Induction and Efficient Plant Regeneration in Three Varieties of Soybean (Glycine max)
}

\author{
Nazrul Islam, Touhidul Islam, Md. Munir Hossain, Bakul \\ Bhattacharjee, M. Monzur Hossain and S. M. Shahinul Islam*
}

Plant Genetic Engineering Laboratory, Institute of Biological Sciences, University of Rajshahi, Rajshahi-6205, Bangladesh

Key words: Cotyledonary node, Embryogenic calli, Regeneration, Somatic embryogenesis, Glycine max

\begin{abstract}
An efficient callus induction and plant regeneration system has been developed using three local soybean (Glycine max L.) varieties. All the varieties showed good callusing (78.30 - 88.80\%) from shoot tip (ST) in MS + $3.0 \mathrm{mg} / 1$ 2,4-D + 1.0 $\mathrm{mg} / \mathrm{l} \mathrm{BAP}$. Best callus induction and embryo formation were recorded in $\mathrm{T}_{5}$ for BS-6 as 88.80 and $81.20 \%$, respectively from ST. In case of cotyledonary node $(\mathrm{CN})$ the maximum callus induction $(82.40 \%)$ and embryo formation $(74.20 \%)$ were recorded also in $\mathrm{T}_{5}$ for BS-6. Highest frequency $(79.40 \%)$ of plant regeneration was recorded where ST were used and cultured in MS supplemented with $2.5 \mathrm{mg} / \mathrm{l} \mathrm{BAP}+1.0 \mathrm{mg} / \mathrm{l} \mathrm{NAA}$ as well as $76.30 \%$ from $\mathrm{CN}$ in BS-6. The length of shoot was observed 5.32 and $4.62 \mathrm{~cm}$, respectively from ST and $\mathrm{CN}$ for BS-6 with the same medium composition. It was observed that half strength of MS $+2.0 \mathrm{mg} / \mathrm{l}$ IBA showed best rooting (9.04). Among the genotypes BS-6 proved to be best explants than ST that exhibited better performance on callus induction and green plant regeneration for all parameters.
\end{abstract}

\section{Introduction}

Soybean is an important oil crop of Fabaceae grown in tropical, subtropical and temperate region. It is now cultivated throughout the east and south-east Asia including Bangladesh and plays an important role in solving the malnutrition in developing countries. Soybean was introduced in Bangladesh a long time ago and it is becoming more popular and the total cropped area is 5000 ha and the total production of the country stands at 4000 ha. It is a potential source of biodiesel and energy in the world and also in Bangladesh (Habibullah et al. 2015).

$\overline{{ }^{*} \text { Author for correspondence: }}<$ shahin_ibsc@ru.ac.bd>. 
There are some reports on tissue culture system for direct organogenesis using embryonic axes (Liu et al. 2004), primary leaf tissues (Wright et al. 1987), cotyledonary nodes (Janani and Kumari 2013), hypocotyls (Reichert et al. 2003), mature and immature cotyledons (Franklin et al. 2004), immature embryos (Ahad et al. 1994, Hong et al. 2007, Islam and Bhattacharjee 2015) and shoot tip (Ugandhar et al. 2011). Cheng et al. (1980) were able to get multiple shoot bud from cotyledonary nodes with high concentrations of BAP. They found that growth improved when the cultures were transferred to MS with low concentrations of BAP. They also reported that BAP, the cells in embryonic axes do not remain quiescent and are reprogrammed to produce multiple somatic foci. In addition of TDZ (thidiazuron) or Kn + BAP showed better performance on embryoids formation from cotyledonary node in soybean (Shan et al. 2005, $\mathrm{Ma}$ and Wu 2008).

Most of the crops are infected by systemic disease caused by fungi, viruses, bacteria, nematode, etc. Meristem and/or shoot tip culture provides a reproducible and economically viable method for producing pathogen free plants (Roy et al. 1994, Ahsan et al. 2003, Jha and Ghosh 2005, Huda and Sikdar 2006). While plant infected by pathogens till there is no commercially available treatment to cure fully infected plants. Soybean is a virus prone seed crop and through tissue culture (shoot-tip or meristem culture) it is possible to develop virus free plants. A major advantage of working with such a small explants is the potential that this holds for excluding pathogenic organisms present in the donor plant through in vitro culture (Alam et al. 2004). Till there is not enough report for soybean's to develop pathogen free plants through advance biotechnological approaches. Under these circumstances the present research work has been undertaken to develop an efficient callus induction and regeneration systems using shoot tip and cotyledonary nodal explants for further advance biotechnological research of soybean in Bangladesh.

\section{Materials and Methods}

Mature seeds of three soybean genotypes viz., BARI Soybean-5 (BS-5), BARI Soybean-6 (BS-6) and Shohag were surface sterilized with $70 \%(\mathrm{v} / \mathrm{v})$ ethanol and then completed the sterilization procedure by $40 \%$ Clorex $(\mathrm{NaOCl} ; \mathrm{ROTH}$, Germany) $+1-2$ drops Tween $20+1-2$ drops savlon. Surface sterilized seeds were then plated in culture vessels that contained $20 \mathrm{ml} \mathrm{MS}$ and incubated them at $25 \pm 2{ }^{\circ} \mathrm{C}$ in dark. The shoot tip and cotyledonary nodal segments of 14 days old seedlings were cut into small pieces and inoculated them in MS that supplemented with six different concentrations of PGRs either singly or in combination for callus induction. Then culture vessels were incubated at $25 \pm 2{ }^{\circ} \mathrm{C}$ 
in dark for $12 \mathrm{hrs}$ photoperiod $(30 \mu \mathrm{mol} / \mathrm{m} / 2 \mathrm{~s})$ provided by white florescent tubes.

The treatments were as follows $\mathrm{T}_{1}=2.0 \mathrm{mg} / 12,4-\mathrm{D} ; \mathrm{T}_{2}=3.0 \mathrm{mg} / 1$ 2,4-D; $\mathrm{T}_{3}=4.0$ $\mathrm{mg} / \mathrm{l} 2,4-\mathrm{D} ; \mathrm{T}_{4}=2.0 \mathrm{mg} / \mathrm{l} 2,4-\mathrm{D}+0.5 \mathrm{mg} / \mathrm{l} \mathrm{BAP} ; \mathrm{T}_{5}=3.0 \mathrm{mg} / \mathrm{l} 2,4-\mathrm{D}+1.0 \mathrm{mg} / \mathrm{l} \mathrm{BAP}$ and $\mathrm{T}_{6}=4.0 \mathrm{mg} / \mathrm{l} 2,4-\mathrm{D}+1.5 \mathrm{mg} / \mathrm{l} \mathrm{BAP}$. After $10-14$ days of inoculation, calli were formed and data were recorded on the basis of callus induction frequencies. Fourteen days old calli were sub-cultured in the same fresh medium for embryo formation. After four weeks of culture, data were recorded on the basis of somatic embryos formation (SEmF). For embryo maturation (EM) four weeks old embryos were transferred to MS supplemented with different concentration of $\operatorname{BAP}(1.5,2.0,2.5,3.0$ and $3.5 \mathrm{mg} / \mathrm{l})+2,4-\mathrm{D}(0.5 \mathrm{mg} / \mathrm{l})$. Afterwards four weeks of culture embryo maturation frequencies were recorded.

After maturation the somatic embryos were transferred to regeneration medium (RM) that was supplemented with different concentrations of BAP (1.5, 2.0, 2.5, 3.0 and $3.5 \mathrm{mg} / \mathrm{l})+1.0 \mathrm{mg} / \mathrm{l}$ NAA. After 4 weeks the lengths of shoots were measured and plant regeneration frequencies were recorded. When length of shoot was around $3-5 \mathrm{~cm}$ transferred them to rooting medium (RIM). Then well rooted plants were transferred to pots and after acclimation plants were transferred to the field.

Data were recorded on the basis of callus induction, embryo formation and its maturation, plant regeneration, shoot length, roots per plants, length of root. The average or mean values were computed from three replications with standard error (SE). The experiment was arranged CRD and data were statistically analyzed by the statistical package software SPSS (version -20) and Microsoft Excel. The analysis of variance (ANOVA) was performed and means were compared by DMRT at 5\% level of probability for interpretation of results (Gomez and Gomez 1976).

\section{Results and Discussion}

Shoot tips and cotyledonary nodal explants were inoculated in CI medium supplemented with 2,4-D (2.0, 3.0 and $4.0 \mathrm{mg} / \mathrm{l})$ either single or in combination with BAP $(0.5,1.0$ and $1.5 \mathrm{mg} / \mathrm{l})$ for callus induction (Fig. 1.). Callus was initiated from the cut ends of both shoot tip and cotyledonary nodal explants in contact the medium within 7 days of culture initiation (Fig. 1B). After 4 weeks of subculture in same medium and PGRs combination clusters of somatic embryos were developed from the embryogenic callus of the explants (Fig. 1C-D). Among the genotypes, BS-6 performed maximum callus induction 88.80 and $82.40 \%$ from ST and CN, respectively in $\mathrm{T}_{5}$ i.e MS augmented with $3.0 \mathrm{mg} / \mathrm{l} 2,4-\mathrm{D}$ in combination with $1.0 \mathrm{mg} / \mathrm{l}$ BAP (Table 1). For embryo formation, BS-6 also 
performed highest 81.20 and $74.20 \%$ from ST and $\mathrm{CN}$, respectively in $\mathrm{T}_{5}$ (Table 1). In case of BS-5 and Shohag, $\mathrm{T}_{5}$ also showed highest callus induction and embryo formation from both ST and CN compared to control (Table 1). The lowest callus induction was recorded for both ST $(47.70 \%)$ and CN $(41.10 \%)$ in $\mathrm{T}_{3}$ for Shohag (Table 1). For embryos formation $\mathrm{T}_{3}$ also showed the lowest from both ST $(23.50 \%)$ and CN $(21.70 \%)$ for Shohag (Table 1). Between the explants ST showed better performance on callus induction and embryos formation than $\mathrm{CN}$ and among the tested genotypes, BS-6 showed better than others.

Table 1. Effect of PGRs on callus induction and somatic embryos formation from shoot tip and cotyledonary node of three soybean varieties.

\begin{tabular}{|c|c|c|c|c|c|}
\hline \multirow[t]{2}{*}{ Variety } & \multirow[t]{2}{*}{ Treatment } & \multicolumn{2}{|c|}{ Shoot tip $(\% \pm$ SE) } & \multicolumn{2}{|c|}{ Cotyledonary node $(\% \pm \mathrm{SE})$} \\
\hline & & $\mathrm{CI}$ & $\mathrm{EF}$ & $\mathrm{CI}$ & $\mathrm{EF}$ \\
\hline \multirow{7}{*}{ BS -5 } & Control & 0 & 0 & 0 & 0 \\
\hline & $\mathrm{T}_{1}$ & $63.30 \pm 1.13^{e}$ & $46.20 \pm 0.81^{\mathrm{cd}}$ & $49.40 \pm 1.22^{\mathrm{b}}$ & $43.60 \pm 1.01^{\mathrm{bc}}$ \\
\hline & $\mathrm{T}_{2}$ & $68.80 \pm 1.36^{\mathrm{fg}}$ & $52.20 \pm 1.15^{\mathrm{e}}$ & $62.70 \pm 1.41^{\mathrm{ef}}$ & $47.20 \pm 1.15^{\mathrm{cd}}$ \\
\hline & $\mathrm{T}_{3}$ & $59.80 \pm 1.51^{\mathrm{d}}$ & $25.70 \pm 0.98^{\mathrm{ab}}$ & $42.40 \pm 0.82^{\mathrm{a}}$ & $23.50 \pm 0.64^{\mathrm{a}}$ \\
\hline & $\mathrm{T}_{4}$ & $71.30 \pm 1.04 \mathrm{gh}$ & $68.70 \pm 0.99 g$ & $68.80 \pm 1.36^{g}$ & $62.80 \pm 0.91^{\mathrm{h}}$ \\
\hline & $\mathrm{T}_{5}$ & $82.20 \pm 1.18^{\mathrm{k}}$ & $77.60 \pm 1.07^{\mathrm{i}}$ & $76.20 \pm 0.78^{\mathrm{h}}$ & $71.90 \pm 1.10^{\mathrm{i}}$ \\
\hline & $\mathrm{T}_{6}$ & $65.70 \pm 0.82^{\mathrm{ef}}$ & $52.40 \pm 0.82^{\mathrm{e}}$ & $53.70 \pm 0.90^{c}$ & $51.40 \pm 0.82^{\text {ef }}$ \\
\hline \multirow{7}{*}{ BS -6} & Control & 0 & 0 & 0 & 0 \\
\hline & $\mathrm{T}_{1}$ & $65.30 \pm 1.22^{\mathrm{ef}}$ & $47.50 \pm 0.89^{d}$ & $58.20 \pm 1.10^{\mathrm{d}}$ & $43.80 \pm 0.85^{\mathrm{bc}}$ \\
\hline & $\mathrm{T}_{2}$ & $75.10 \pm 0.82^{\mathrm{ij}}$ & $53.20 \pm 1.57 \mathrm{e}$ & $71.30 \pm 1.24 \mathrm{~g}$ & $48.50 \pm 1.46^{\mathrm{de}}$ \\
\hline & $\mathrm{T}_{3}$ & $56.50 \pm 1.23^{c}$ & $28.50 \pm 0.78^{b}$ & $48.80 \pm 1.15^{b}$ & $24.20 \pm 1.24^{a}$ \\
\hline & $\mathrm{T}_{4}$ & $76.90 \pm 1.18^{j}$ & $74.50 \pm 1.40^{\mathrm{hi}}$ & $70.90 \pm 1.23 \mathrm{~g}$ & $62.20 \pm 1.18^{\text {gh }}$ \\
\hline & $\mathrm{T}_{5}$ & $88.80 \pm 0.93^{1}$ & $81.20 \pm 1.15^{j}$ & $82.40 \pm 1.36^{\mathrm{i}}$ & $74.20 \pm 1.56^{\mathrm{i}}$ \\
\hline & $\mathrm{T}_{6}$ & $73.30 \pm 1.05^{\mathrm{hi}}$ & $71.30 \pm 1.16^{\mathrm{gh}}$ & $64.50 \pm 1.19^{f}$ & $62.30 \pm 1.16^{\mathrm{gh}}$ \\
\hline \multirow{7}{*}{ Shohag } & Control & 0 & 0 & 0 & 0 \\
\hline & $\mathrm{T}_{1}$ & $52.10 \pm 0.67^{b}$ & $43.30 \pm 1.47^{c}$ & $48.80 \pm 1.04^{\mathrm{b}}$ & $40.30 \pm 1.18^{b}$ \\
\hline & $\mathrm{T}_{2}$ & $65.60 \pm 0.87^{e f}$ & $47.20 \pm 0.61^{\mathrm{d}}$ & $59.60 \pm 1.25^{\mathrm{de}}$ & $45.60 \pm 0.96^{\mathrm{cd}}$ \\
\hline & $\mathrm{T}_{3}$ & $47.70 \pm 0.95^{a}$ & $23.50 \pm 1.31^{\mathrm{a}}$ & $41.10 \pm 0.89^{a}$ & $21.70 \pm 1.18^{a}$ \\
\hline & $\mathrm{T}_{4}$ & $67.30 \pm 1.52^{\mathrm{f}}$ & $68.50 \pm 1.18 \mathrm{~g}$ & $63.30 \pm 1.54^{\mathrm{f}}$ & $58.90 \pm 1.37 \mathrm{~g}$ \\
\hline & $\mathrm{T}_{5}$ & $78.30 \pm 1.06^{j}$ & $71.60 \pm 0.87 \mathrm{gh}$ & $71.20 \pm 0.91 \mathrm{~g}$ & $65.80 \pm 1.76^{\mathrm{h}}$ \\
\hline & $\mathrm{T}_{6}$ & $65.80 \pm 0.83^{\text {ef }}$ & $59.50 \pm 1.19^{f}$ & $58.30 \pm 0.87^{\mathrm{d}}$ & $53.40 \pm 1.45^{\mathrm{f}}$ \\
\hline
\end{tabular}

Control $=\mathrm{MS}_{0}$, different superscripts letter(s) in a column indicate significant different at $\mathrm{p}<0.05$ levels according to DMRT. $\mathrm{T}_{1}=2.0 \mathrm{mg} / \mathrm{l} 2,4-\mathrm{D} ; \mathrm{T}_{2}=3.0 \mathrm{mg} / \mathrm{l} 2,4-\mathrm{D} ; \mathrm{T}_{3}=4.0 \mathrm{mg} / 1$ $2,4-\mathrm{D} ; \mathrm{T}_{4}=2.0 \mathrm{mg} / 1$ 2,4-D + $0.5 \mathrm{mg} / \mathrm{l} \mathrm{BAP} ; \mathrm{T}_{5}=3.0 \mathrm{mg} / \mathrm{l} 2,4-\mathrm{D}+1.0 \mathrm{mg} / \mathrm{l} \mathrm{BAP} ; \mathrm{T}_{6}=4.0 \mathrm{mg} / \mathrm{l}$ 2,4-D + $1.5 \mathrm{mg} / \mathrm{l} \mathrm{BAP} . \mathrm{CI}=$ Callus induction, $\mathrm{EF}=$ Embryo formation .

Suitable embryos were sub-cultured on MS supplemented with BAP (1.5 - 3.5 $\mathrm{mg} / \mathrm{l}$ ) $+0.5 \mathrm{mg} / \mathrm{l}$ 2,4-D for development and maturation of somatic embryos (Fig. 1E). In addition $2.5 \mathrm{mg} / \mathrm{l} \mathrm{BAP}+0.5 \mathrm{mg} / 1$ 2,4-D promoted the highest $(76.60 \%)$ 
maturation of somatic embryos found in BS-6 from shoot tips (Fig. 2). The BS-5 and Shohag exhibited 74.80 and $71.30 \%$ embryos maturation, respectively in the same medium and plant growth regulators (Fig. 2). It was observed that ST explants originated embryos showed better embryo maturation than $\mathrm{CN}$.
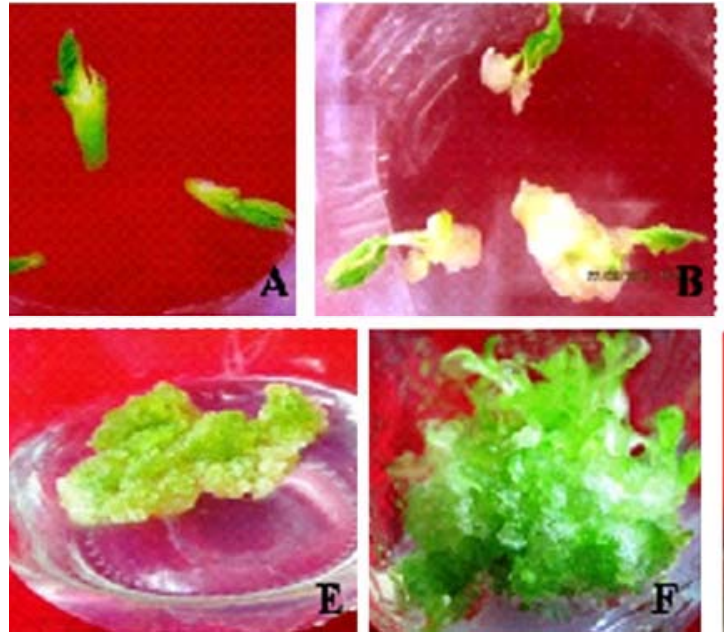
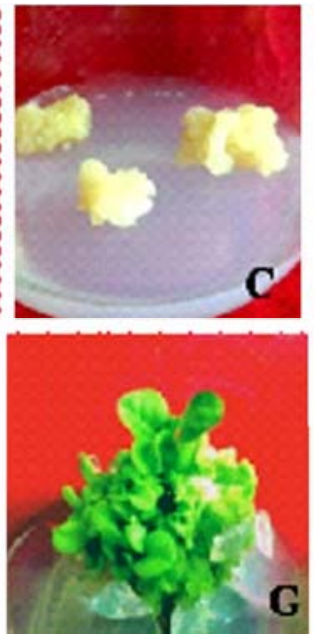

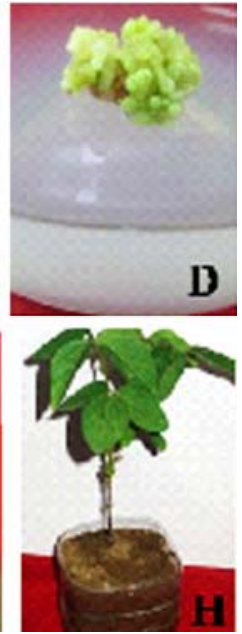

Fig. 1 (A-H): Regenerated plants derived from shoot tip in soybean. A. Inoculated shoot tips, B-C. Callus induction from shoot tips, D. Somatic embryos formation from embryogenic callus, E. Matured embryos becoming to be greenish, F. Regenerated shoots from mature embryos, G. Green plantlets, H. Acclimated plants transferred to pot.

The globular embryos were transferred to regeneration medium for shoot induction. It was observed that MS in combination with BAP and NAA exhibited significant results on shoot induction (Table 2, Fig. 1F). The highest regeneration frequencies (79.40 in BS-6, 76.40 in BS-5 and 75.70\% in Shohag) were recorded from shoot tip in MS + $2.5 \mathrm{mg} / \mathrm{l} \mathrm{BAP}+1.0 \mathrm{mg} / \mathrm{l} \mathrm{NAA}$ (Table 2). To observe the effect of growth regulators on shoot elongation (Fig. 1G), five different types of hormonal combinations were evaluated and the maximum lengths of shoot were recorded $5.32 \mathrm{~cm}, 4.75 \mathrm{~cm}$ and $4.35 \mathrm{~cm}$ in BS-6, BS-5 and Shohag, respectively. In this case as explants ST were used and cultured them in MS + $2.5 \mathrm{mg} / \mathrm{BAP}+1.0$ $\mathrm{mg} / \mathrm{l}$ NAA. Here, lowest shoot length was recorded for Shohag $(2.42 \mathrm{~cm})$ in MS + $3.5 \mathrm{mg} / \mathrm{l} \mathrm{BAP}+1.0 \mathrm{mg} / \mathrm{l} \mathrm{NAA}$ that derived from $\mathrm{CN}$ (Table 2). Between the explants ST originated regeneration frequencies and lengths of shoots higher than $\mathrm{CN}$. Considering all the treatments for shoot regeneration, it was evident that BAP $(2.5 \mathrm{mg} / \mathrm{l})$ performed better in combination with $1.0 \mathrm{mg} / \mathrm{l}$ NAA (Fig. $1 G)$. 
Table 2. Effect of BAP in combination with $1.0 \mathrm{mg} / 1 \mathrm{NAA}$ on plant regeneration and shoot elongation of three soybean varieties.

\begin{tabular}{|c|c|c|c|c|c|}
\hline \multirow{2}{*}{ Variety } & \multirow{2}{*}{$\begin{array}{l}\begin{array}{l}\text { PGRs } \\
(\mathrm{mg} / \mathrm{l})\end{array} \\
\text { BAP }\end{array}$} & \multicolumn{2}{|c|}{ Shoot tip } & \multicolumn{2}{|c|}{ Cotyledonary node } \\
\hline & & $\begin{array}{l}\text { Regeneration } \\
(\% \pm \mathrm{SE})\end{array}$ & $\begin{array}{l}\text { Shoot length } \\
(\mathrm{cm} \pm \mathrm{SE})\end{array}$ & $\begin{array}{c}\text { Regeneration } \\
(\% \pm S E)\end{array}$ & $\begin{array}{l}\text { Shoot length } \\
(\mathrm{cm} \pm \mathrm{SE})\end{array}$ \\
\hline \multirow{6}{*}{ BS -5 } & Control & 0 & 0 & 0 & 0 \\
\hline & 1.50 & $42.20 \pm 1.10^{b}$ & $3.01 \pm 0.06^{\mathrm{ab}}$ & $38.20 \pm 1.18^{a}$ & $2.98 \pm 0.15^{\mathrm{abcd}}$ \\
\hline & 2.00 & $61.80 \pm 0.89^{\mathrm{ef}}$ & $4.12 \pm 0.13^{\text {ef }}$ & $54.80 \pm 1.43^{c}$ & $3.64 \pm 0.13^{\text {defg }}$ \\
\hline & 2.50 & $76.40 \pm 0.83^{\mathrm{hi}}$ & $4.75 \pm 0.15 \mathrm{~g}$ & $71.20 \pm 0.55^{f}$ & $4.35 \pm 0.24^{\mathrm{hi}}$ \\
\hline & 3.00 & $63.90 \pm 1.14^{\mathrm{f}}$ & $4.12 \pm 0.12^{\mathrm{ef}}$ & $52.80 \pm 1.20^{c}$ & $3.46 \pm 0.18^{\text {cdefg }}$ \\
\hline & 3.50 & $51.10 \pm 0.70^{c}$ & $3.35 \pm 0.15^{\mathrm{bc}}$ & $43.40 \pm 1.67^{b}$ & $2.75 \pm 0.28^{\mathrm{ab}}$ \\
\hline \multirow{6}{*}{ BS-6 } & Control & 0 & 0 & 0 & 0 \\
\hline & 1.50 & $44.80 \pm 1.30^{\mathrm{b}}$ & $3.65 \pm 0.10^{\text {cde }}$ & $41.50 \pm 1.48^{\mathrm{ab}}$ & $3.24 \pm 0.11^{\text {bcdef }}$ \\
\hline & 2.00 & $68.20 \pm 1.07 \mathrm{~g}$ & $4.39 \pm 0.15^{\mathrm{fg}}$ & $64.60 \pm 1.18^{\mathrm{de}}$ & $3.91 \pm 0.25^{\mathrm{fgh}}$ \\
\hline & 2.50 & $79.40 \pm 1.37^{\mathrm{i}}$ & $5.32 \pm 0.10^{\mathrm{h}}$ & $76.30 \pm 1.44^{\mathrm{g}}$ & $4.62 \pm 0.24^{\mathrm{i}}$ \\
\hline & 3.00 & $65.20 \pm 1.13^{\mathrm{fg}}$ & $4.47 \pm 0.14^{\mathrm{fg}}$ & $61.90 \pm 0.89^{d}$ & $3.79 \pm 0.42^{\text {efgh }}$ \\
\hline & 3.50 & $52.20 \pm 1.70^{c}$ & $3.39 \pm 0.16^{\mathrm{bcd}}$ & $43.80 \pm 1.00^{\mathrm{b}}$ & $3.14 \pm 0.06^{\text {bcde }}$ \\
\hline \multirow{6}{*}{ Shohagh } & Control & 0 & 0 & 0 & 0 \\
\hline & 1.50 & $38.30 \pm 1.29^{a}$ & $3.05 \pm 0.13^{\mathrm{ab}}$ & $37.90 \pm 1.15^{\mathrm{a}}$ & $2.82 \pm 0.12^{\mathrm{abc}}$ \\
\hline & 2.00 & $56.80 \pm 1.43^{\mathrm{d}}$ & $3.85 \pm 0.08^{\mathrm{de}}$ & $52.10 \pm 1.53^{c}$ & $3.42 \pm 0.24^{\text {bcdefg }}$ \\
\hline & 2.50 & $75.70 \pm 1.00^{\mathrm{h}}$ & $4.35 \pm 0.09^{\mathrm{fg}}$ & $67.70 \pm 1.46^{\mathrm{ef}}$ & $4.08 \pm 0.16^{\mathrm{ghi}}$ \\
\hline & 3.00 & $59.50 \pm 1.37$ de & $3.76 \pm 0.31$ cde & $53.80 \pm 1.80^{c}$ & $3.26 \pm 0.11^{\text {bcdef }}$ \\
\hline & 3.50 & $44.60 \pm 1.24^{\mathrm{b}}$ & $2.76 \pm 0.20^{\mathrm{a}}$ & $39.90 \pm 1.40^{\mathrm{ab}}$ & $2.42 \pm 0.19^{a}$ \\
\hline
\end{tabular}

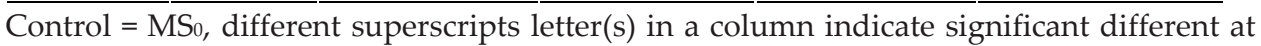
$\mathrm{p}<0.05$ levels according to DMRT.

It was observed that IBA significantly influenced on root development for the three tested genotypes (Fig. 1H). The results indicated that both explants showed an increasing trend with both parameters (number and length of roots) with the increase of IBA concentration up to $2.0 \mathrm{mg} / \mathrm{l}$. Significant differences were found on the number of roots/shoot due to the effect of IBA. The highest roots/shoot (9.04) was recorded with $2.0 \mathrm{mg} / \mathrm{l}$ IBA in BS-6 from ST and lowest was in Shohag (3.40) with $3.0 \mathrm{mg} / \mathrm{l}$ IBA when CN were used as explants sources. On the other hand, root length showed highest in BS-6 $(4.57 \mathrm{~cm})$, and thereafter BS-5 $(4.27 \mathrm{~cm})$ and Shohag $(4.17 \mathrm{~cm})$ in the same medium from ST (Data Table and Figs are not shown herein). Between the two explants ST showed better performance than $\mathrm{CN}$ in case of roots number and length.

After acclimation, the plants were transferred into pots (Fig. 1H) and then cultured in the field of natural condition. Here, MS and in combinations with 2,4$\mathrm{D}+\mathrm{BAP}$ showed significant variation in embryogenic callus induction whereas single uses of 2,4-D showed less number of embryogenic calli. Kumari et al. 
(2006) reported that combined effect of 2,4-D and BAP showed similar type of results using their genotypes. Another studies of soybean 2,4-D has been the most commonly used auxin for induction of callus and somatic embryogenesis (Ranch et al. 1985, Mariashibu et al. 2013). Callus induction was reported in soybean within 7 days of inoculation (Settu and Ranjithakumari 1999) and Jang et al. (2001) found callus initiation after 10 - 14 days of culture initiation. In this

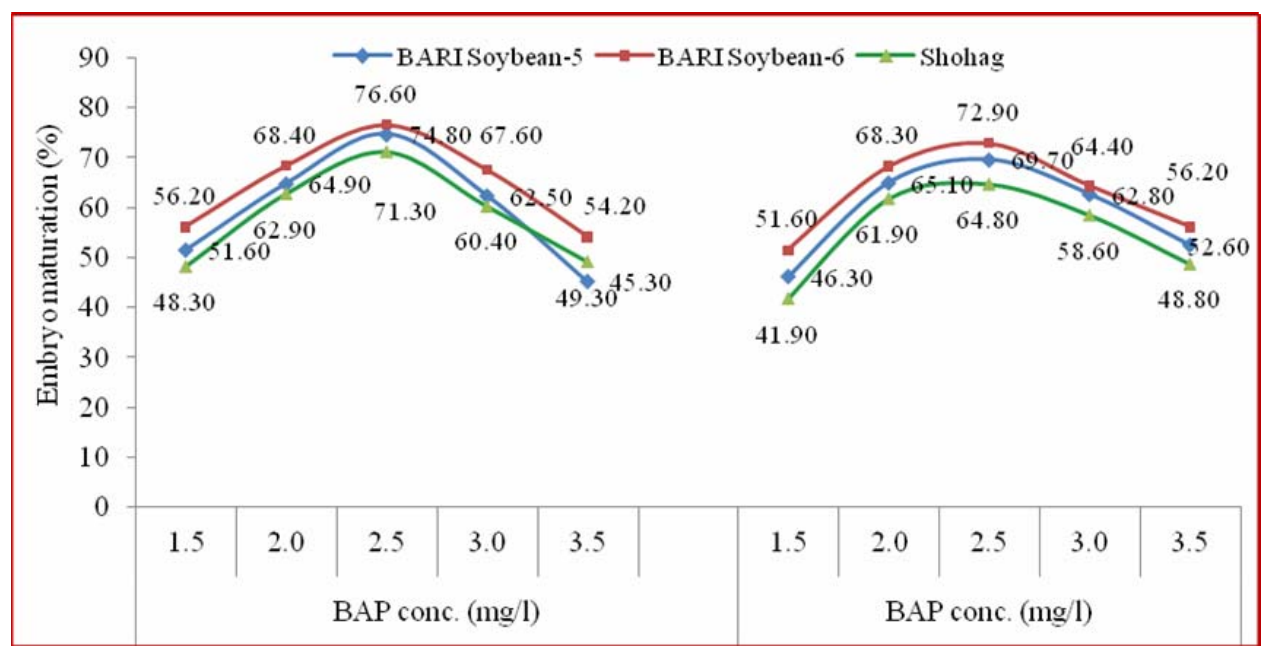

Fig. 2. Effect of BAP in combination with $0.5 \mathrm{mg} / \mathrm{l}$ 2,4-D on maturation of somatic embryos.

experiment the genotypic differences and growth regulators type might be causes shorter duration for callus induction. Present results indicated that higher concentration of BAP $(2.5 \mathrm{mg} / \mathrm{l})$ with lower doses of 2,4-D $(0.5 \mathrm{mg} / \mathrm{l})$ increased embryo maturation. Lazzeri et al. (1987) and Tian et al. (1994) were reported that positive effect of the cytokinins on somatic embryogenesis in soybean. McKently (1991) reported that when the auxin concentration was increased, the probability of a normal shaped embryo was decreased. Higher concentration of auxin not only decreased the number of embryos but also delayed embryogenesis (Reddy and Reddy 1993). Kim et al. (2001) observed that 8.0 roots/shoot when $1.5 \mathrm{mg} / \mathrm{l}$ IBA used singly. Yuan et al. (2001) reported that when as PGRs, IBA added in MS the root formation was enhanced. Liu et al. (1998) observed that suitable root formation in MS with $2.0 \mathrm{mg} / \mathrm{l}$ IBA. Bhojwani and Razdan (1983) reported that using auxins in the medium enhanced root formation in plants. 


\section{Acknowledgements}

Fellowship provided to first author (NI) by the University Grant Commission (UGC) of Bangladesh is gratefully acknowledged. Thanks are also due to Bangladesh Agriculture Research Institute (BARI), Gazipur, Bangladesh for providing soybean seeds.

\section{References}

Ahad A, Islam R, Hossain M Khalekuzzaman M and Joarder OI (1994) Plant regeneration from immature and mature embryo axes of watermelon. MSc Thesis, Department of Botany, Rajshahi University, Bangladesh.

Ahsan N, Hossain SA, Alam MF, Hossain MM, Islam R and Sultana RS (2003) Virus free potato tuber seed production through meristem culture in tropical Asia. Asian J. Plant Sci. 2(8): 616-622.

Alam MF, Banu MLA, Swaraz AM, Parvez S, Hossain M, Khalekuzzaman M and Ahsan N (2004) Production of virus free seeds using meristem culture in tomato plant under tropical conditions. J. Plant Biotechnol. 6(4): 221-227.

Bhojwani SS and Razdan MK (1983) Plant tissue culture, theory and practice. In: Development in crop science (5). Elsevier, Amsterdam, Oxford, New York, Tokyo. pp. 25-41.

Cheng TY, Saka H and Voqui-Dinh TH (1980) Plant regeneration from soybean cotyledonary node segment in culture. Plant Sci. Lett. 19(2): 91-99.

Franklin G, Carpenter L, Davis E, Reddy CS, Al-Abed D, Alaiwi W, Parani M, Smith B, Goldman SL and Sairam RV (2004) Factors influencing regeneration of soybean from mature and immature cotyledons. Plant Growth Reg. 43(1): 73-79.

Gomez KA and Gomez AA (1976) Statistical procedures for agricultural research. IRRI (ed.), Philippines. pp. 10-119.

Habibullah M, Masjuki HH, Kalam MA, Ashrafur Rahman SM, Mofijur M, Mobarak HM and Ashraful AM (2015) Potential of biodiesel as a renewable energy source in Bangladesh. Renewable Sust. Energy Rev. 50: 819-834.

Hong HP, Zhang H, Olhoft P, Hill S, Wiley $H$, Toren E, Hillebrand $H$, Jones $T$ and Cheng M (2007) Organogenic callus as the target for plant regeneration and transformation via Agrobacterium in soybean (Glycine max (L.) Merr.). In Vitro Cell Dev. Biol. Plant. 43: 558-568.

Huda AKMN and Sikdar B (2006) In vitro plant production through apical meristem culture of bitter gourd (Momordica charantia L.). Plant Tissue Cult. \& Biotech. 16(1): 31-36.

Islam SMS and Bhattacharjee B (2015) Plant regeneration through somatic embryogenesis from leaf and root explants of Rhynchostylis retusa (L.) Blume". Appl. Biol. Res. 17(2): 158-165.

Janani C and Kumari BDR (2013) In vitro plant regeneration from cotyledonary node and half seed explants of Glycine max L. (JS335). Ann. Biol. Res. 4(11): 60-66. 
Embryogenic Callus Induction and Efficient Plant Regeneration

Jang GW, Park RD and Kim KS (2001) Plant regeneration from embryogenic suspension cultures of soybean (Glycine max L. Merr.). J. Plant Biotech. 3(2): 101-106.

Jha TB and Ghosh B (2005) Plant tissue culture basic and applied, Universities Press, New Delhi, India.

Kim HK, Park HK, Park MS and Ye UD (2001) Effects of auxins and cytokinins on organogenesis of soybean Glycine max L. J. Plant Biotech. 3(2): 95-100.

Kumari BD, Settu A and Sujatha G (2006) Somatic embryogenesis and plant regeneration in soybean [Glycine max (L.) Merr.]. Indian J. Biotech. 5: 243-245.

Lazzeri PA, Hilderbr DF and Collins GB (1987) Soybean somatic embryogenesis: Effects of hormones and culture manipulations. Plant Cell Tiss. Org. Cult. 10: 197-200.

Liu HK, Yang C and Wei ZM (2004) Efficient Agrobacterium tumefaciens-mediated transformation of soybean using an embryonic tip regeneration system. Planta 219: 1042-1049.

Liu ZH, Wang WC and Yan SY (1998) Effect of hormone treatment on root formation and endogenous indole-3-acetic acid and polyamine levels of Glycine max cultivated in vitro. Bot. Bull. Acad. Sin. 39: 113-118.

Ma HH and Wu TL (2008) Rapid and efficient regeneration in soybean [Glycine max (L.) Merrill.] from cotyldenary node explants. Acta Physiol. Planta 30(2): 209-216.

Mariashibu TS, Subramanyam K, Arun M, Mayavan S, Rajesh M, Theboral J, Anickavasagam M and Ganapathi A (2013) Assessment of somatic embryogenesis potency in Indian soybean [Glycine max (L.) Merr.] cultivars. Acta Physiol. Plant. 35: 41-54.

McKently AH (1991) Direct somatic embryogenesis from axes mature peanut embryos. In Vitro Cell Dev. Biol. 27: 197-200.

Ranch JP, Ogelshy L and Zielinski AC (1985) Plant regeneration of somatic embryos from all suspension cultures of soybean. In Vitro Cell Dev. Biol. 21: 653-658.

Reddy RI and Reddy GM (1993) Factors affecting direct somatic embryo genesis and plant regeneration in ground nut (Arachis hypogea L.). India J. Exp. Biol. 33: 57-60.

Reichert NA, Young MM and Woods AL (2003) Adventitious organogenic regeneration from soybean genotypes representing nine maturity groups. Plant Cell Tiss. Org. Cult. 75(3): 273-277.

Roy SK, Hossain MZ and Islam MS (1994) Mass propagation of Rauvolfia serpentina by in vitro shoot tip culture, Plant Tiss. Cult. 4(2): 69-75.

Settu A and Ranjithakumari BD (1999) In vitro plant regeneration from leaf explants of soybean \{Glycine max (L.) Merr.\}. Plant Tiss. Cult. 9(1): 11-16.

Shan Z, Raemakers K, Tzizikas EN, Ma ZQ and Visser RGF (2005) Development of a highly efficient, repetitive system of organogenesis in soybean [Glycine max (L.) Merr.]. Plant Cell Rep. 24(9): 507-512.

Tian LNM, Brown PL, Voldeng H and Webb J (1994) In vitro response and pedigree analysis for somatic embryogenesis of long day photoperiod 'adopted soybean. Plant Cell Tiss. Org. Cult. 36: 269-273. 
Ugandhar T, Venkateshwarlu M, Parvathi D, Shekar GPV, Srilatha T and Aganmohan Reddy KJ (2011) High frequency somatic embryogenesis and plantlet regeneration from shoot tip explants of soybean. Sci. Res. Rep. 1(3): 146-150.

Wright MS, Ward DV, Hinchee MA, Carnes MG and Kaufman RJ (1987) Regeneration of soybean (Glycine max) from cultured primary leaf tissue. Plant Cell Rep. 6(2): 83-89.

Yuan Y, Liu DP, Zheng PH, Xu WJ and Li HL (2001) Study on plant regeneration from soybean culture. Soybean Sci. 20(1): 9-13. 